\title{
THE ACCIPITERS
}

SIGVALD O. JORDHEIM, White Bear, Saskatchewan. SOL 3LO

The three species of accipiters which occur in Saskatchewan are quite different from most of our hawks, in looks, action and temperament. All three have the rounded wings and long tail of the accipiter and are quite similar in color; size is the recognised difference.

The smallest member of the family, the Sharp-shinned Hawk, being no larger than a Kestrel, is adept at catching the smaller songbirds in their own environment, pursuing them right among the hedges and bushes. Their wings often come in contact with the branches.

The middle-sized, the Cooper's Hawk, is capable of killing larger birds up to the size of pigeons, partridge and small chickens. This past summer a Cooper's Hawk followed pigeons into a building and killed several birds, so they seem to have an urge to kill beyond their needs. This particular bird was captured and placed in a wire crate, with intention to release it some distance away, but it constantly threw itself against the sides of the crate and next morning it was dead.

The Northern Goshawk, the largest member of the family, is a formidable enemy to game birds and pigeons, being secretive, swift and very persistent. They come skimming close to the ground, across open fields and gracefully glide up into a tree, and with scarcely a movement of wings will alight among the branches and there sit motionless, scanning the surrounding countryside for possible prey. When the prey is spotted they drop almost to the ground and with rapid wingbeats build up tremendous speed and even pigeons which are faster then many birds will find the goshawk right among the flock despite their efforts. If the pigeon can outmanoeuvre it three or four times the hawk tires and will glide gracefully down and again land in a tree or on some other vantage point and patiently sit until the pigeons, after much circling will eventually alight, when it will make another attempt.

When the farm flock of 100 pigeons wish to go in the coop, which has small $4 \times 5^{\prime}$ openings, there is much fluttering and one particular goshawk soon learned that this was a very good time to move in and capture one. Soon the pigeons changed their tactics and with the flock circling above the coop, six or eight pigeons would drop down and quickly get inside. The flock would make another circle and if the hawk was not coming, another few birds would plunge down and enter the building. If the hawk was advancing the whole flock would climb to greater heights to foil the hawk. When it alighted the flock would come to a lower altitude and again a few at a time would gain the safety of the coop, until finally they were all inside.

Hunting was becoming less productive for the hawk and one day it pursued some bantam chickens into a wire pen in front of the henhouse. I closed the door, captured the hawk, banded and sprayed some green paint on its tail and underparts so it could be identified at a distance, then put it in the same wire box the Cooper's Hawk had been in, but it too beat itself against the sides. Fearing it would injure itself, I put it in a cardboard box, but even in that, the bird jumped and thumped constantly. I drove some $20 \mathrm{~km}$ in a north- easterly direction and released the hawk, which immediately flew in a south-easterly direction. 